\title{
Discussing Mang Robe System of Ming and Qing Dynasties
}

\author{
Yuan Wang \\ School of Fashion \& Art Design, Donghua University \\ Shanghai 200051, China \\ Shanghai Institute of Visual Art, Fudan University \\ Shanghai 200061, China \\ E-mail:wyuan111@tom.com
}

\begin{abstract}
There were systems of Mang robes both in Ming and Qing dynasties. However, they differ greatly in style although they have got the same name. A Mang robe in Ming Dynasty has big and wide body and sleeves, the same style as that of Han nationality. But the Mang robes of the Qing Dynasty bear the features of typical nomadic style with turtle neck, buttons on the right side, and horse-hoof sleeves. Although the Qing Mang robe system is from the Ming dynasty, only those external ornaments that can be accepted by the rulers remain. Rulers of Qing Dynasty believed that ornaments were only used to decorate the garments and there was no need to rigidly adhere to the external form.
\end{abstract}

Keywords: Ming Dynasty, Qing Dynasty, Mang robe

\section{Introduction}

There were systems of Mang robes in Ming Dynasty, which was established by Han nationality and Qing Dynasty, which was set up by the Manchu. In the early period of the Qing Dynasty, ethnic tradition in clothing was stressed. But system of Mang robe was borrowed from the Ming dynasty. In addition, the system of Bufu and use of the twelve ornaments were all from clothing of those dynasties established by the Han people. The rulers of the Qing Dynasty believed that clothing system was closely linked with the regime and the clothing style with Manchu national characteristics was fundamental for the clothing system. Patterns worked as decoration and never affected the nature of clothing.

Officials of Ming Dynasty took Mang robes as the court apparel. As for Qing Dynasty both the Princes and those officials who do not belong to the nine grades can wear them. Xu Ke of the Qing Dynasty wrote in his works of Qingbaileichao that wearing Mang robes, which have another name of motley, is a system of the Ming Dynasty. Shen Defu of the Ming Dynasty in his book of Yehuobian said that the python patterns in the Mang robe were similar with the dragon patterns with the only difference of absence of one paw. He proposed that Mang robe of Qing Dynasty was undoubtedly the motley of the Ming Dynasty. (Xu, 1986, p6176). Since Mang robe system follows that of the Ming Dynasty, are the styles of the Mang robe of the Ming and Qing Dynasties the same? Or are there any differences between them?

\section{Mang robes of the Ming dynasty}

\subsection{The basic appearance of Mang robes}

Mang robes get the mane for the embroidered python on them. In the Ming Dynasty, they are not listed in official costume. Many scholars believe that the Mang robes are a concept of rewarded articles. It is generally believed that Mang robes are at the beginning of Zhengtong (1436 - 1449) were given to the early leaders of other nations, which can be proved by what Shen Defu said in Yehuobian. (Shen, p830). Still there are other scholars who hold different views. It was recorded that right in the $15^{\text {th }}$ year of Yongle (1405), more than 30 years earlier than the beginning of Zhengtong period, three kings of Sulu kingdom were presented with Mang robes. "They were rewarded respectively with a waist belt made of jade, a-hundred Liang gold, two-thousand-Liang platinum... and a piece of clothing of a python pattern embroidered with gold threads. " From then on, in the first year of Hongzhi (1488), in the $13^{\text {th }}$ year of Zhengde (1354), the $16^{\text {th }}$ year of Zhengde (1357), the $3^{\text {rd }}$ year of Jiajing (1524), the $42^{\text {nd }}$ of Jiajing (1563), the $14^{\text {th }}$ year of Wanli (1586), the $38^{\text {th }}$ year of Wanli (1610), there were records about the rewarding of the Mang robes.(Song, 2001). Mang robes were 
rewarded to such figures as Liu Jian, Li Dongyang, Xujie, Zhang Juzheng and others of the Ming Dynasty. (Zhang, 1997). It was of course a great honor to receive a piece of clothing from emperors.

In addition to the costume as a reward, the Mang robes function as sacrifice garments in the Ming Dynasty. Every time when the emperors presided over the sacrifice rites, all the civil and military officials should be present in the sacrifice garments. In the $8^{\text {th }}$ year of Jiajing, the garments that officials should wear on sacrifice rites were determined and in those days or months when the emperors held the sacrifice rites, all the Jinyiwei were in red Mang robes.

From the text above it can be seen that Mang robes possess a high status in the Ming Dynasty and there is a rigid restrictions of the grade that people belong to. Those who disobey the regulations will receive a felony. In the second year of Tianshun (1458), it was prescribed that ordinary officials and civilians could not use python or flying fish as clothing patterns. The colors of yellow, purple, black, green, turmeric and bright yellow could not also be allowed to use. In the $13^{\text {th }}$ year of Hongzhi (1500), it was provided that "if the dukes, marquises, earls, civil and military officials, occupation commissioners, and Shoubei do not obey the regulations but wear the garments with embroidered patterns of python and flying fish, they will receive a felony." In the $16^{\text {th }}$ year of Zhengde (1521), Shizong emperor ascended the throne and prescribed an edict that strictly prohibited officials to violate the rules to use the belt made of jade and use the garments with patterns of embroidered python and flying fish. It was still noted that it should be prohibited that a number of relatively low rank officials adopted the clothing color which should be used by dukes and marquises. Ming Dynasty strictly provided the use of python patterns on clothing. Even if similar patterns are not allowed. For example, there was a book of History of Ming Dynasty saying that in the $16^{\text {th }}$ year of Jiajing (1537) an official named Zhang Zan wore a garment with a similar pattern of python. Shizong emperor got great furious and questioned that why Zhangzan could wear a Mang robe since he was only a second rank official. Another official mamed Xiayan answered that the garment Zhang Zan wore was rewarded by the emperor. It was embroidered with flying fish, only a little similar with a python. So Shizong emperor said how a flying fish could have two horns, as should be strictly prohibited. (Zhang, 1997).

\subsection{Several forms of python patterns}

Python patterns on Mang robes of the Ming dynasty are not single but display various manifestations, sometimes faced or profile and sometimes round or disk .... According to History of the Ming Dynasty, from the $10^{\text {th }}$ year of Zhengde (1515) to the $15^{\text {th }}$ year of Chongzhen (1642), Emperors of the Ming Dynasty, in various names, rewarded the garments embroidered python patterns to tens of officials such as Xia Yan, Xu Jie, Ma Fang, Zhang Juzheng, Li Liangcheng, Ye Xianggao, Fang Congzhe, Zhang Heming, Sun Chengzong, Wang Pu, Sun Yingyuan, and He Fengsheng, etc. These Mang robes were named as "red sitting python" (faced python), "circling python", and "embroidered python", etc. The python patterns were placed differently on robes. According to some documents, after Yongle, the eunuchs must wear Mang robes when standing by the emperors. Their python samples, generally speaking, were embroidered on the both sides of robe. There is another kind of garment decorated with mandarin squares with embroidered python patterns and python patterns on the knees. (Zhang, 1997). As what Liu Ruoyu said in ZhuoZhongzhi, Recorded Poems by Drinkers, some eunuchs of the Ming Dynasty who got favored did want they wanted to risk violating the regulations to have the Mang robes made. There was a garment named Tieli at that time. Since Wei Zhongxian got favored, python patterns were used on Tieli. There was another garment with embroidered python patterns inside and outside of both sleeves. From the time of visiting lanterns in lunar January until the winter solstice, the python patterns on the Mang robe have been changed with the seasons, for example, in Double Ninth festival in September, python patterns and chrysanthemum patterns are combined to decorate the apparel. Wei Zhongxian also created the apparel embroidered with tiger, rabbit and hyacinth patterns in gold thread to suit for the occasions of the emperors' birthdays or national celebrations. (Liu, 1993, p263-264).

\section{Insert Figure 1 and Figure 2 here}

The above text displays that python patterns of the Ming Dynasty can be embroidered on both sides of the garment, on mandarin squares, on keens and on sleeves. With the different seasons, python patterns demonstrate different manifestations. In accordance with the provisions of the Ming Dynasty, python patterns stand for high or low ranks and the faced python patterns stand for the highest position. Python patterns are divided into five-paw and four-paw ones. The more the python have paws, the nobler the position it stands for. (Zhang, 1997). Although the Ming Dynasty has strict requirements for wearing the Mang robes, virtually, in the late Ming Dynasty, it is almost out of control about using Mang robes. The original faced sitting python stands for the noblest but it was abused by some officials later.

According to the different position of apparel that python patterns are on, it may be inferred that Mang robes of the Ming Dynasty can be divided into two styles.

The first is of turtle neck, surplice sleeves with the python patterns all over the body. This type of Mang robes can be seen more in the pictures of the officials of the Ming Dynasty. Figure 1 is the photo of Li Zhen of the Ming Dynasty in blue Mang robe. Figure 2 is the handed down collection in Chongqing Municipal Museum cherished by the official Qing Liangyu of the late Ming Dynasty. The blue Mang robe is made in silk and embroidered with golden clouds and 
python patterns. The robe is of the standing collar, surplice sleeves with 75 centimeters wide. It is 171 centimeters long and the sleeve is 96.5 centimeters in length. The horizontal neckline is 14 centimeters wide and the vertical is 8 centimeters deep. The waist is 69 centimeters wide and the bottom is 140 centimeters wide. As can be seen from the picture, Figure 1 and Figure 2 are the same style of Mang robes. Both are of turtle collar and surplice sleeve, with buttons on the right, and the python patterns all over the body. The python patters on the two pictures are not the faced sitting but the profile climbing pythons.

The second is of the python patterns embroidered on the mandarin squares. Such garments are of more diversified forms. According to History of the Ming Dynasty, in the late period of Yongle, the garments worn by eunuchs are decorated with mandarin squares of patterns on the chest and back, and on the knees there are woven with clouds and pythons horizontally. In addition, the garments mentioned above with woven python patterns on both sleeves also use python patterns on the mandarin squares on the chest and back.

\section{Mang robe of the Qing Dynasty}

\section{Insert Figure 3 here}

\subsection{The basic appearance of Mang robe}

Mang robes of the Qing Dynasty can be worn matching with the mandarin squares. Those who are qualified for wearing the mandarin squares are eligible to wear Mang robes.

Styles of Mang robes of the Qing Dynasty can be found in Illustrations of Imperial Ritual Paraphernalia. Figure 3 is the Mang robe of the princes and the seventh-class Mang robe of civil officials. Both are of the same style with the similar patterns. It is difficult to see the differences of the Mang robes worn by the people of different identities only from the pictures. More concrete details should be turned to the written records. For instance, in accordance with the provisions of the Qing Dynasty, "the golden yellow Mang robes used by the princes are embroidered with nine pythons all over the body. The color of blue can be used by the Mang robes worn by the infantes. But they can use golden yellow if it is allowed by the emperors. While the Mang robes used by the baylors are not allowed to use golden yellow and they are embroidered with nine-paw python patterns. As for the Mang robes worn by forth-class civil officials, they can use blue or rock blue as they like and the whole body can be embroidered with eight-paw python patterns, so are the fifth-class, sixth-class military officials, fifth-class, sixth-class civil officials, and Fengen generals. Mang robes worn by the seventh-class civil officials can adopt blue or rock blue and the whole body can be embroidered with four-paw python patterns, so do the seventh-class, eighth-class, ninth-class military officials and eighth-class, ninth-class civil officials. "(Yun, 2004, p126, p130, p138, p158, p180, p200). Guangxu of the Qing Dynasty had more detailed records about the differences of the Mang robes of various identities. Only the royal members have front and back, left and right split downswings while the others only have front and back split downswings. (Note 1).

As can be known from the written records and illustrations, the basic style of the Mang robes of the Qing Dynasty is of turtle collar, buttons on the right side, horse-hoof sleeves with embroidered python patterns all over the body. The differences of different ranks are embodied in color, the number of python patterns, and the number of paws. Mang robes are divided into four or two split downswings, and the former is of the noble one.

\subsection{Occasions for wearing Mang robes}

In the late Qing Dynasty, Mang robes and BUFU are often used to symbolize the official honors. In the $24^{\text {th }}$ year of Qianlong when Illustrations of Qianlong Ritual Paraphernalia was edited, a system of Mang robes fitting for mandarin squares was supplemented. However, the matching wearing of Mang robes and mandarin squares does not begin from Qianlong, it exists long before that.

Take the $52^{\text {nd }}$ year of Kangxi for instance, as every March 8 is the birthday of the emperor, all the officials except kings should wear Mang robes and mandarin squares in Changchun garden. However, it was right the $60^{\text {th }}$ birthday of the emperor, which is not comparable to the normal days. From the first day to the last day of March, court dresses, Mang robes and Bufu should be worn. In the following years, for every ten years it should be taken as an example. (Note 2). Because the $6^{\text {th }}$ year of Yongzheng was the queen's birthday, all the officials must wear the Mang robes and Bufu.(Note 2). And the $16^{\text {th }}$ year of Qianlong was the birthday of the emperor's mother, the emperor was in dragon robe. All the maharajahs and ministers in Mang robe and Bufu, and noble ladies of Manchu and Han in colorful suits knelt down at the side of the street waiting for the coming of the emperor... It was prescribed in this year that the $25^{\text {th }}$ of November was the sixth birthday of the emperor's mother and from the fourteenth day to the twenty-eighth day, all the maharajah and ministers should wear Mang robes and Bufu. (Note 2). Figure 4 is a part of the Qing Dynasty Palace painting of Rewarded Banquet in Wanshu Palace. It shows that in the $19^{\text {th }}$ year of Qianlong Duerbote Mongolian tribe led by its leader Sancheling claimed their allegiance to the Qing Dynasty and the occasion on which emperor Qianlong gave a banquet to treat Sancheling and other people in Chengde Imperial Summer Resort. In the following year the picture was painted. What the officials wear in the picture is Bufu. More similar scenes can be seen in the whole picture. In some unearthed goods of Qing officials, Mang robes and Bufu can be found in matching one with another. For instance, in 
2006, in Yuquan road, Shijing Hill of Beijing city, a corpse of a Qing official was unearthed. The body was dressed in Bufu. When it was taken off, there was inside a blue Mang robe with a five-paw golden dragon embroidered on the chest and back. At present the relevant cultural relics are stored in the Capital Museum.

In the Qing Dynasty, Mang robes are worn matching with Bufu. However, emperors of the Qing Dynasty rewarded the Mang robes to the officials in order to show their grace and favor. For example, in the $3^{\text {rd }}$ year and the $13^{\text {th }}$ year of Qianlong, the emperor gave Yansheng duke a Mang robe as a largess. (Note 3). In this sense, Mang robes of the Qing Dynasty get the same function as those of Ming Dynasty.

\section{Conclusions}

All the Mang robes of Ming and Qing Dynasties are decorated with python patterns. Although they have got the same name but they are different in style and in purpose.

\subsection{In the Ming Dynasty, Mang robes belong to the clothing that was rewarded to the officials.}

It is a great honor to win such a garment. In addition, when in the ritual of sacrifice, some officials of the special identities can also wear Mang robes. Mang robes stand for a higher status in the Ming Dynasty and only those who are of a certain rank can wear them.

Mang robes of the Qing Dynasty can be dressed in matching with the Bufu. Those who are qualified for wearing Bufu all can wear the Mang robes in line with their identities. Sometimes the emperors would present Mang robes to the officials. In this sense, Mang robes of the Qing Dynasty get the same function as those of the Ming Dynasty.

\subsection{Mang robes of the Ming Dynasty were of the robe style, which can be roughly divided into two categories.}

One is the robe of turtle collar, sleeves of ample dimensions with python patterns all over the body. The other is that python patterns are used on mandarin square. As for costumes of the Ming dynasty, the location of python patterns is not fixed. Either in both sides, or on mandarin square, or on knees, or inside or outside of the sleeves is suitable. Mang robes are of the high or low rank for different numbers of the python patterns and python paws.

Mang robes worn by different identities of the Qing Dynasty are of the same style, turtle collar, narrow horse-hoof sleeves and python patterns all over the body. The different social statuses were displayed mainly in color, the number of python patterns and the python claws. There are differences of the downswings of four-side split ends, which is noble, and two-side split ends.

Although the system of Mang robes of the Qing Dynasty inherited from the Ming Dynasty, what is reserved is the external ornamentation that can be accepted only by the rulers. Rulers of the Qing Dynasty emphasized that the characteristics of nomadic dress should be retained, style was basic for clothing, and such a superficial form as the patterns of the clothing did not need too much prohibiting.

\section{References}

Liu, Ruoyu (Ming Dynasty). (1993). Records by Drinkers: brief introduction to the costumes by Neichen. Bashu Book Company.

Shen, Defu (Qing Dynasty). Wangli Yehuobian. Beijing: Zhonghua Book Company.

Song, Junhua. (2001). Exploring the Mang Yi and discussing the dressing-up of the military officers in Palace plays. Journal of Sun Yatsen University (Social Science Edition).

Xu, Ke (Qing Dynasty). (1986). Qingbaileichao. Beijing: Zhonghua Book Company.

Yun, Lu (Qing Dynasty). (2004). Illustrations of Imperial Ritual Paraphernalia. Yangzhou: Guanling Book Company.

Zhang, Tingyu (Qing Dynasty). (1997). Twenty-four Histories (History of the Ming Dynasty). Beijing: Zhonghua Book Company.

\section{Notes}

Note 1. Records of Laws and Systems of the Qing Dynasty in Guangxu Period: Crown Closing System. The Imperial Collections of Four. Shanghai: Shanghai Guji Publishing House.

Note 2. Cases of Record of Laws and Systems of the Qing Dynasty. Vol. 56

Note 3. Cases of Imperial records of Laws and Systems of the Qing Dynasty. Vol. 309. Part of History. Supplementary Imperial Collections of Four. Shanghai: Shanghai Guji Publishing House. Pp. 6,7. 


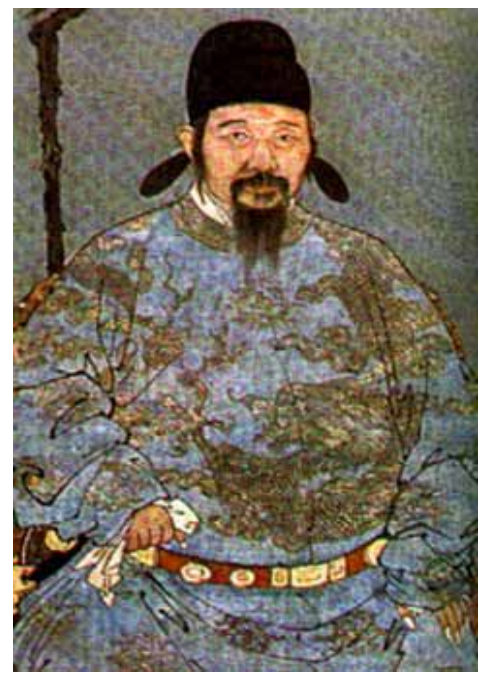

Figure 1. Picture of Li Zhen of Ming Dynasty

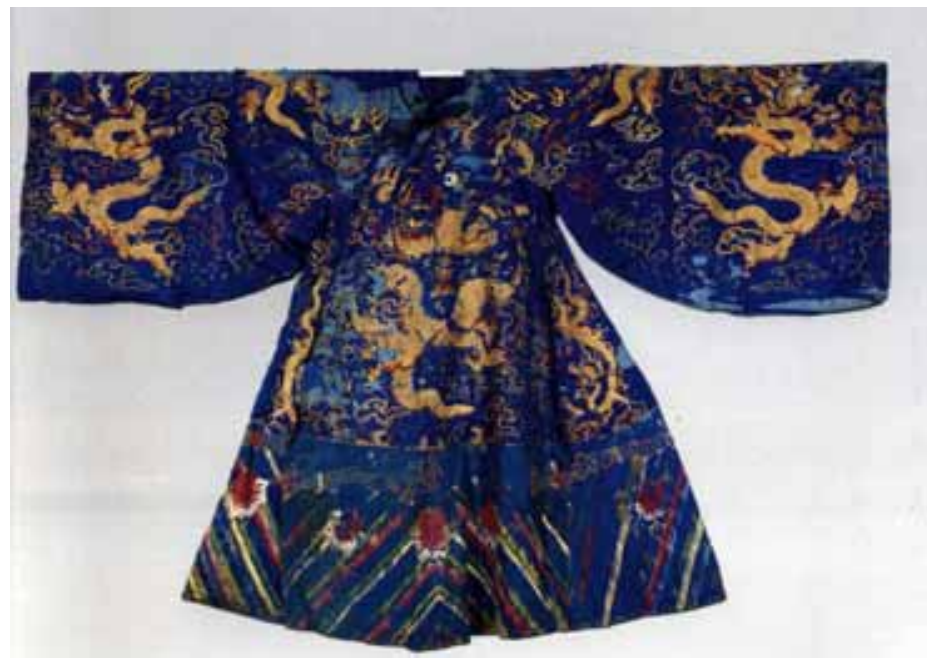

Figure2.AHanded-downarticle: theblue goldsickMangrobeembroidered with python pattems ownedbyQin liangyuoftheMingDynasty
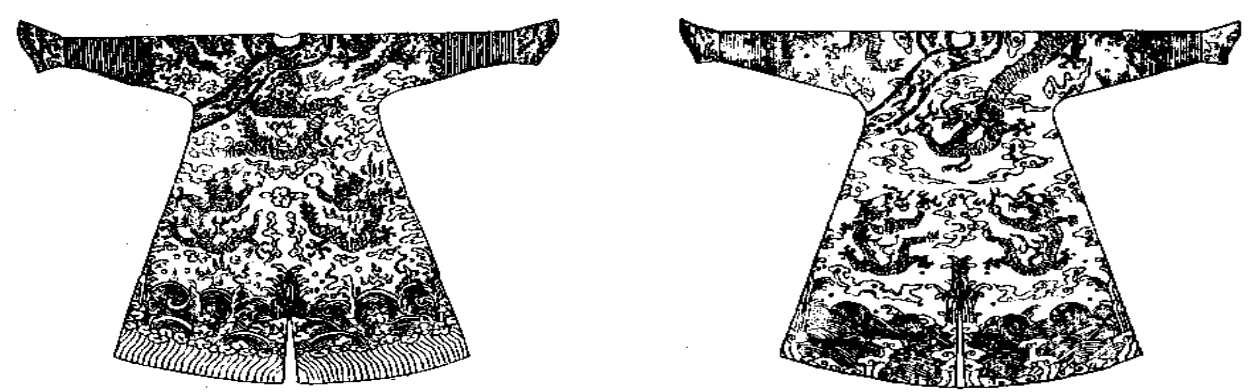

Figure 3. Mang robes wom by Princes or seventh grade civil officials in Illustrations of Imperial Ritual Paraphemalia

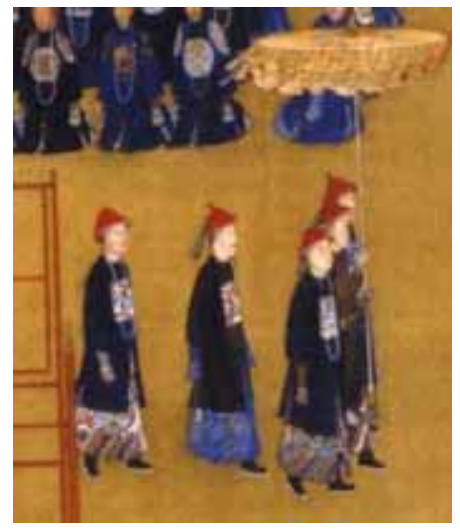

Figure 4. Part of Rewarded Banquet in Wanshu Palace and officials in Mang robe andBufu. 